Vol. 44, N. 2 : pp. 129 - 134, June, 2001

ISSN 1516-8913 Printed in Brazil

AN INTERNATIONAL JOURNAL

\title{
Influence of Temperature and Diet on the Development of Ulomoides dermestoides (Fairmaire, 1893) (Coleoptera, Tenebrionidae, Diaperinae)
}

\author{
Renato C. Marinoni* and Cibele S. Ribeiro-Costa \\ Departamento de Zoologia, Universidade Federal do Paraná. Caixa Postal, 19020. Centro Politécnico, 81531- \\ 990, Curitiba - PR, Brazil
}

\begin{abstract}
Ulomoides dermestoides (Fairmaire, 1893) develops in stored food products (peanuts, maize, oats, rice, sorghum, etc.) and breeds successfully in the laboratory. To determine the best conditions for development, experiments were set up in different temperatures and diets, similar to storage conditions of peanuts (Arachis hypogaea $L$.). The higher viability of individuals and the shorter developmental time were observed in the diet composed of hulls and seeds of fruits at 21 and $24^{\circ} \mathrm{C}$.
\end{abstract}

Key words: Coleoptera, Ulomoides dermestoides, peanuts, diet, temperature, moisture

\section{INTRODUCTION}

Ulomoides dermestoides (Fairmaire, 1893) is a euryphagous and cosmopolitan species, considered as a restorative on the southeast coast of China, and then as a panacea around the world, purporting to cure any illness (Yoshida, 1974; Chua \& Chandrapal, 1978; Dacanay \& Cervancia, 1989). It is a species that develops in stored food products, and has been used in laboratory experiments because it is easy to breed. The purposes of this work was to improve the knowledge of the effects of different physical and biological parameters on the development of stored food insects; and analyze the influence of different temperatures and storage conditions of peanuts (Arachis hypogaea L.) in order to develop for better rearing conditions for Ulomoides dermestoides.

\section{MATERIALS AND METHODS}

The development of Ulomoides dermestoides was tested in three different conditions of peanut storage in four chambers with controlled temperatures $\left(18,21,24\right.$ and $\left.27^{\circ} \mathrm{C}\right), 12$ hours photophase and moisture at $65 \pm 5 \%$. For each diet, in each temperature, two replications were established. The diets were: only grains (diet "A"); open fruits (hulls + seeds) (diet "B"); complete fruits (diet "C").

The individuals (pupae) used in tests were removed from a stock culture maintained under natural variations of temperature and having only seeds of peanuts as a food resource. The pupae were selected to form five pairs for each replication, then placed in Petri dishes and kept at four controlled temperatures. After the eclosion from pupae, adults were transferred to plastic 500 $\mathrm{ml}$ receptacles, with 50 grams of peanuts in the three conditions quoted above.

\footnotetext{
Author for correspondence
} 
The receptacles, with adults and food, were examined daily after the first emergence of pupa (first generation). Each pupa detected was sorted by sex and transferred to another receptacle with the same conditions of food and temperature. The number of individuals and the duration of development (days) were noted. The date of first pupal emergence from the second receptacle (second generation) was considered the last day of the first generation and, at this time, the replication was concluded.

As the experiments started in the pupal stage, the period for the appearance of first pupae of the first generation was considered as being the duration of the life cycle. The mean time of the life cycle was the result of the average time (days) of the development of individuals, during the interval defined by the period of emergence of all pupae of the first generation until the emergence of the first pupae of the second generation.

The number of individuals and days of development obtained for males and females, diets " $A$ " and "B", were not significantly different $(P>0.90)$, so the values were treated together.

Statistical analyses were performed based on $\mathrm{X}^{2}$ test to evaluate differences in data of viability between diets and the $\mathrm{F}$ test to evaluate the differences of developmental time, considering the diets and the four temperatures.

The voucher material has been deposited in the Museu de Entomologia Pe. Jesus S. Moure, Departamento de Zoologia, Universidade Federal do Paraná.

\section{RESULTS AND DISCUSSION}

Ulomoides dermestoides developed in the diets "A" and "B" but not in the diet " $C$ ".

Viability (Table 1, Figure 1). The diet "B" (open fruits $=$ hulls + seeds) was favorable to the development of a higher number of individuals compared with diet "A" (only seeds) (1061:286; $\left.\mathrm{X}^{2}=230.83, \mathrm{P}<0.0001\right)$. The most extremely different values where those observed in the experiment at $27^{\circ} \mathrm{C}$, as there were 331 individuals in the diet "B" and only nine in diet "A".

Extensive data are available quoting a trend of better development in higher temperatures (Hafez \& El-Ziady, 1952; Ray, 1960; Atwal \& Sethi,
1977; Kasten Junior \& Parra, 1984; Almeida \& Marinoni, 1986), until the upper limit of the optimal range of temperature was reached (Chapman, 1982). In the experiment with Ulomoides dermestoides, however, more individuals were observed in the intermediate temperatures ( 21 and $24^{\circ} \mathrm{C}$ ), on both diets, except in the experiment at $27^{\circ} \mathrm{C}$, on diet "B" .

Because our results showed that intermediate temperatures were more favorable for the species viability, two points must be discussed: 1) at $21^{\circ}$ $\mathrm{C}$, the number of individuals on diet "B" was four times higher than that observed on diet "A"; 2) at $27^{\circ} \mathrm{C}$ on diet " $\mathrm{B}$ ", the number of individuals was 30 times higher than on diet " $\mathrm{A}$ ". In the former, the results appeared to be influenced by a combination of two factors: temperature and the physical environment of diet " $\mathrm{B}$ ". In the latter, the expected results at $27^{\circ} \mathrm{C}$ would be a lesser number of individuals than that at $24^{\circ} \mathrm{C}$, following the tendency observed on diet "A". The changing of the tendency could be explained by the different condition provided by diet "B", probably increasing the moisture.

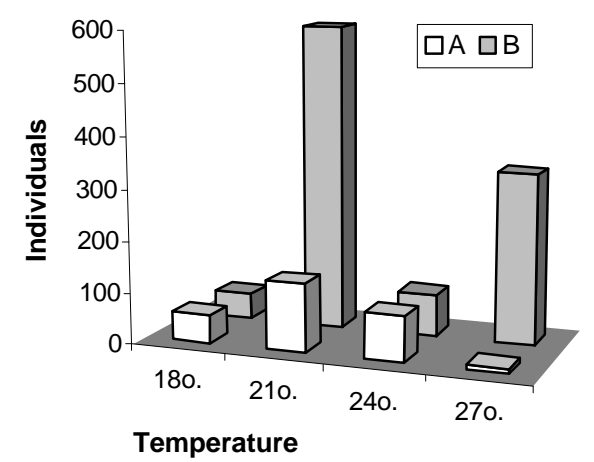

Figure 1 - Ulomoides dermestoides. Number of individuals reared in peanuts, diets " $A$ " and "B", at different temperatures.

Atwal \& Sethi (1977) reported the influence of moisture on the viability of Epilachna vigintioctopunctata Fabricius (Coleoptera, Coccinellidae); the results showed that higher moisture (40-70\%) determine an increase, almost proportional, of the percentage of surviving larvae (58.2-82.2\%). Butler (1949), observed that the highest moisture was favorable to larvae survival of Palorus ratzeburgi Wissman (Tenebrionidae, Ulominae), and commented that the females fed on wheat, at lower moisture level, laid a lesser number of eggs. 
When Chua \& Chandrapal (1978) compared their fecundity data on $U$. dermestoides with those of Yoshida (1974) experiments, they stated that the observed higher number of eggs laid could be due to the rate, amount, and type of food. The authors, however, made no mention of the moisture, which was higher in their experiments $(61-75 \%, 81-$ $86 \%$ ). Possibly, the feature of diet "B" responsible for providing differences in moisture, was of a structural nature. There were bigger spaces surrounding hulls and grains, probably contributing to an increase in the moisture than in the diet composed only of grains. A higher moisture level probably was an advantage for the species development, favouring a higher number of individuals reaching the end of their life cycles. At high moistures, the insect evaporative cooling produced by the heat of metabolic activity was reduced, being favorable to maintain the hydric balance and, in consequence, the survival (Chapman, 1982).

It appeared that moisture was the factor that most affected the viability rather than the nutritive components of diet "B". After Gohl (1981), the chemical composition of hulls (zero-moisture basis) is: $4.9 \%$ crude protein, $68.4 \%$ crude fiber,
$7.4 \%$ ash, $0.6 \%$ ethereous extract and $18.7 \%$ nitrogen free extract; the seed composition is: 21.0-36.4 \% protein, $35.8-54.2 \%$ fat, $6.0-24.9 \%$ total carbohydrate, $1.2-4.3 \%$ fiber, $1.8-3.1$ ash, 4$13 \%$ moisture, fractions of essencial elements. Fiber is the principal component of hulls whereas in seeds protein, fats and carbohydrates predominate.

Another effect that has been indicated as inducing alterations in values of fecundity, viability and developmental time is the overcrowding (Chua \& Chandrapal, 1978; Peters \& Barbosa, 1977; Yoshida, 1974). The possible influence of population size leading to food scarcity has not affected the lower number of individuals on diet "A", because the same food supply was offered in both diets.

\section{Developmental time of life cycle}

The life cycle was longer on diet "B" than on diet "A" (F test, significantly different $\mathrm{P}<0.001$ ). The experiment on diet "B", at $27^{\circ} \mathrm{C}$, was the exception, with lesser value comparing with that on diet "A", possibly also as a consequence of moisture (Table 1, Figure 2).

Table 1 - Values of viability and developmental time of Ulomoides dermestoides(Fairmaire, 1893), reared in peanuts, diets "A" and "B", at different temperatures.

\begin{tabular}{|c|c|c|c|c|c|c|}
\hline & \multicolumn{6}{|c|}{ Temperatures } \\
\hline & diets & $18^{\circ}$ & $21^{\circ}$ & $24^{\circ}$ & $27^{\circ}$ & Total \\
\hline \multirow[t]{3}{*}{ Number of individuals } & A & 55 & 133 & 89 & 9 & 286 \\
\hline & $\mathrm{B}$ & 51 & 597 & 82 & 331 & 1061 \\
\hline & & & & & & Average \\
\hline \multirow[t]{2}{*}{ Developmental time (days) of life cycle } & A & 117 & 81 & 68 & 89 & 89 \\
\hline & $\mathrm{B}$ & 155 & 81 & 92 & 58 & 97 \\
\hline \multirow[t]{2}{*}{ Mean time (days) of development of life cycle } & A & 161 & 117 & 87 & 115 & 120 \\
\hline & B & 198 & 112 & 127 & 76 & 128 \\
\hline \multirow{2}{*}{$\begin{array}{l}\text { Mean rate of the number of individuals by the mean } \\
\text { time of development of life cycle }\end{array}$} & A & 0.34 & 1.14 & 1.02 & 0.08 & 0.65 \\
\hline & B & 0.26 & 5.33 & 0.65 & 4.36 & 2.65 \\
\hline
\end{tabular}




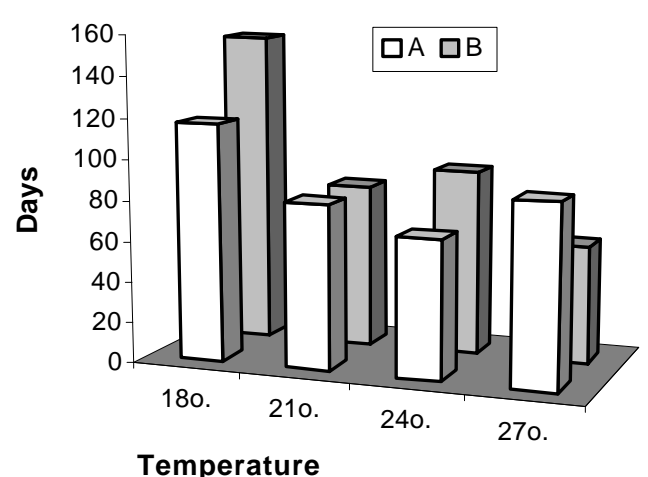

Figure 2 - Ulomoides dermestoides reared in peanuts. Developmental time of life cycle, diets " $A$ " and "B", at different temperatures.

The results clearly showed a relation of higher viability with shorter developmental time. A negative correlation was found between the values of viability (number of individuals) and developmental time (number of days), independent of the diets ( "A": $r=-0.405$; "B": $r=-0.609$ ).

Considering both diets ("A" and "B") at the intermediate temperatures ( 21 and $24^{\circ} \mathrm{C}$ ), the developmental time was shorter than at temperature extremes $\left(18\right.$ and $\left.27^{\circ} \mathrm{C}\right)$. There was a significant difference ( $\mathrm{F}$ test, $\mathrm{P}>0.6$ ) comparing the values, even considering the shortest time observed at temperature of $27^{\circ} \mathrm{C}$, diet "B". The mean time of development of life cycle showed the same proportional values among experiments as that of time of development (defined by the emergence of first pupae of the first generation) (Table 1, Figures 2 and 3).

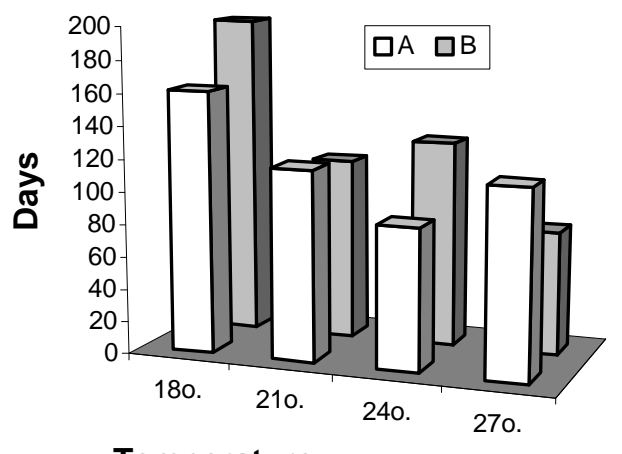

Temperature

Figure 3 - Ulomoides dermestoides reared in peanuts. Mean time of development of life cycle, diets "A " and "B", at different temperatures.
Yoshida (1974), Chua \& Chandrapal (1978), and Dacanay \& Cervancia (1989), studying the development of $U$. dermestoides at around $30^{\circ} \mathrm{C}$ reported following times: 50,56 and 42 days. The mean time reported here at $27^{\circ}$, on both diets (11576 days) (Table 1, Figure 3) was higher than that of these authors, contradicting to the expected results of a decrease in developmental time at higher temperatures.

Hagstrum \& Milliken (1988) analyzed the influence of temperature, moisture and diet on the life cycle of many coleopterous species of stored products. The authors demonstrated that the effect of temperature was the most important on the developmental time, followed by moisture and diet; however, near each species optimal temperature of development changes in moisture and diet seemed to influence the developmental time more than changes in temperature. They also observed that at high temperatures, some species (Tribolium confusum Jacqueline DuVal, Cryptolestes ferrugineus Stephens) increased the developmental time at low moisture. Their data contradict the tendency of shorter developmental time under higher temperatures. Analyzing the data of Howe (1960) upon larvae of Tribolium confusum, it was possible to conclude that at the same temperature the developmental time was shorter at higher moisture. The same tendency was observed in the data of Fenilli (1982) who studied the developmental time of $U$. dermestoides larvae, at the same temperature and two moisture levels (65\% and 70\%). Dias (1993) registed that their results on developmental time of U.dermestoides were more similar to those of Yoshida (1974), than those of Chua \& Chandrapal (1978), probably as a function of the moisture.

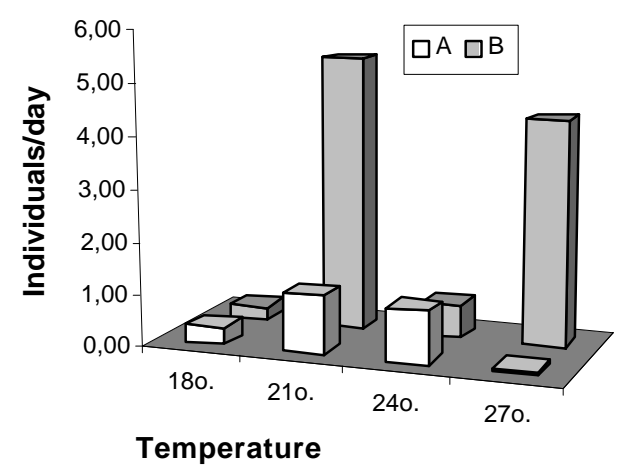

Figure 4 - Ulomoides dermestoides. Mean number of individuals emerged per day, in diets "A" and "B", at differents temperatures. 
The mean rate of individuals per day (Table 1, Figure 4) (number of emerged pupa divided by the mean of developmental time at each temperature) was proportionally similar to the total number of individuals within the same diet. The trend was similar, increasing the number of individuals per day in intermediate temperatures on both diets, except for the experiment on diet "B", at $27^{\circ} \mathrm{C}$. In diet "B", the results indicated better conditions of development, because the number of individuals per day was higher than in the diet "A" $(2.65$ 0.65 ). At $27^{\circ} \mathrm{C}$, the rate was near of those at $21^{\circ} \mathrm{C}$.

\section{CONCLUSIONS}

Ulomoides dermestoides (Fairmaire, 1893) showed higher viability when reared in open fruits (hulls and seeds) of peanut (Arachis hypogaea), compared with the diet composed only of seeds and they did not develop in complete fruits. On the diet of open fruits, they exhibited higher viability and shorter developmental times in intermediate temperatures and probably better conditions of development (viability and developmental time) at higher moisture levels.

\section{ACKNOWLEDGMENTS}

We would like to thank Antonio Panizzi, Clarence Dan Johnson and Irineu Lorini for their constructive review of the manuscript; James Ropper for the suggestions about the statistical analyses; and Conselho Nacional de Desenvolvimento Científico e Tecnológico for the research fellowships.

\section{RESUMO}

Ulomoides dermestoides (Fairmaire, 1893) é um coleóptero que se desenvolve em produtos armazenados (amendoim, milho, aveia, arroz, sorgo, etc.) e é facilmente criado em laboratório. Para avaliar as melhores condições de desenvolvimento foram estabelecidos experimentos em diferentes temperaturas e em dietas definidas por três diferentes condições de armazenamento de amendoim (Arachis hypogaea L.). A maior viabilidade de indivíduos e o menor tempo de desenvolvimento foram verificados na dieta constituída por frutos abertos (vagens e grãos) e em temperaturas de 21 e $24^{\circ}$ C. É discutida a possível influência da umidade relativa nos resultados.

\section{REFERENCES}

Almeida, L. M. and Marinoni, R. C. (1986), Desenvolvimento de três espécies de Epilachna (Coleoptera:Coccinellidae) em três combinações de temperatura e fotoperíodo. Pesquisa Agropecuária Brasileira, 21, 927-939

Atwal, A. S. and Sethi, S. L. (1977), Influence of different levels of temperature and moisture on the speed of development and survival of Epilachna vigintioctopunctata F. (Coleoptera: Coccinellidae). Indian Journal of Ecology, 4, 91-93

Butler, P. M. (1949), Observations on the biology of Palorus ratzeburgi Wissman, with comparative notes on Tenebrionidae in general (Coleoptera). Transactions of Royal Entomological Society of London, 100, 249-273

Chapman, R. F. (1982), The Insects. Structure and Funcion. Harvard University Press, Cambridge. 919p

Chua, T. H. and Chandrapal, R. (1978), The influence of restricted food supplies on the development of larvae and on the fecundity of Palembus dermestoides Fairn. (Tenebrionidae). Journal of Stored Products Research, 14, 81-86

Dacanay, A. A. and Cervancia, C.R. (1989), Biology of Palembus (Martianus) dermestoides Chevrolat (Coleoptera; Tenebrionidae). Philippines Ent., 7, 471477

Dias, E. A. R. (1993), Caracterização de Ulomoides dermestoides (Fairmaire, 1893) (Coleoptera, Tenebrionidae) criado em amendoim e milho. Master of Sciences Thesis, Pontifícia Universidade Católica do Rio Grande do Sul, Porto Alegre, Brazil)

Fenilli, R. (1982), Ciclo biológico, morfologia e efeitos da radiação gama $\left({ }^{60} \mathrm{CO}\right)$ em adultos de Palembus dermestoides (Fairmaire, 1893) (Coleoptera, Tenebrionidae). Doctor of Sciences Thesis, Universidade de São Paulo, Piracicaba, Brazil)

Gohl, B. (1981), Tropical feeds. Feed information summaries and nutritive values. FAO Animal Production and Health Series 12. FAO, Roma

Hafez, M. and El-Ziady, S. (1952), Studies on the biology of Hyperaspis vinciguerrae Capra, with a full description of the anatomy of the fourth stage larva (Coleoptera, Coccinellidae). Bull. Soc. Fouad Entomol., 36, 211-246

Hagstrum, D. W. and Milliken, G. A. (1988), Quantitative analysis of temperature, moisture, and diet factors affecting insect development. Annals of Entomological Society of America, 81, 539-546 
Howe, R. W. (1960), The effects of temperature and humidity on the rate of development and the mortality of Tribolium confusum Duval (Coleoptera, Tenebrionidae). Annals of Applied Biology, 48, 363376

Kasten Junior, P. and Parra, J. R. P. (1984), Bioecologia de Alabama argillacea. I. Biologia em diferentes temperaturas, na cultivar de algodoeiro IAC-17. Pesquisa Agropecuária Brasileira, 19, 269-280

Peters, T. M. and Barbosa, P. (1977), Influence of population density on size, fecundity, and developmental rate of insects in culture. Annual Review of Entomology, 22, 431-450
Ray, C. (1960), The application of Bergmann's and Allen's rules to the poikilotherms. Journal of Morphology, 106, 85-108

Yoshida, T. (1974), Rate of oviposition and effect of crowding on egg cannibalism and pre-adult mortality in Martianus dermestoides Chevrolat (Coleoptera, Tenebrionidae). The Scientific Reports of the Faculty of Agriculture Okayama University, 44, 9-14

Received: January 06, 2000; Revised: April 17, 2000; Accepted: August 10, 2000. 